\title{
Female Consumers Recreational Shopping Experiences
}

\author{
Sarbjot Singh*, Piyush Kumar Sinha**, HariGovind Mishra*** \\ *Shri Mata Vaishno Devi University, Jammu (J\&K), India \\ **Indian Institute of Management, Ahmedabad, India \\ ***Shri Mata Vaishno Devi University, Jammu (J\&K), India
}

\begin{tabular}{|c|c|}
\hline ARTICLE INFO & A B S T RACT \\
\hline $\begin{array}{l}\text { Keywords: } \\
\text { Recreational, } \\
\text { Leisure, } \\
\text { Shoppers, } \\
\text { Shopping behavior, } \\
\text { mall experience }\end{array}$ & $\begin{array}{l}\text { The study examines the core meaning of intrinsic shopping to } \\
\text { understand their experimental aspects of recreational and leisure } \\
\text { shopping. The study focus only on female shoppers of age group } \\
\text { ranging from 25-30, and understand their mall experiences because } \\
\text { this segment is newly transform into self dependent segment which } \\
\text { have less social and familial liabilities and have enough enthusiasm } \\
\text { to explore the world or their boundaries. The Grounded theory use for } \\
\text { identification of recreational shopping themes which are (a) seeking } \\
\text { experiences and (b) experimental shopping and each have respective } \\
\text { sub themes. The themes are connected to the key idea that shoppers } \\
\text { are motivated by their expectations and desires. The study uses social } \\
\text { constructivism to find and understand the shopper meanings in real } \\
\text { terms rather than imposing and judgment on them. The findings } \\
\text { described the way people do recreational shopping and how shopping } \\
\text { malls use as leisure space and become facilitators of recreational } \\
\text { shopping activities. Females use malls to fulfill their recreational } \\
\text { and leisure shopping experiences as this is the great way of enjoying } \\
\text { shopping for females of small towns. In malls females not only enjoy } \\
\text { product experiences but services experiences also which makes their } \\
\text { shopping interesting. The way the female of this age category use malls } \\
\text { help the marketers and retailers to understand this segment shopping }\end{array}$ \\
\hline Corres & patterns. \\
\hline
\end{tabular}

\section{INTRODUCTION}

Shopping malls are the suitable example of recreational and leisure shopping. It provides leisure and social space (Martin and Turley, 2004), and consumer like to spend more time in shopping malls, than any other public place (Guiry, 1999). Shopping is means for satisfying both personal and social priorities (Dawson et al., 1994), and it is related with experimental aspects, intrinsic rewards, hedonic values (Guiry \& Lutz, 2000), symbolic product meanings, variety and novelty-seeking (Slama, \& Rogers, 1985). Leisure shopping is related to freedom and 
quality of experiences for enjoyment, but not for survival. Dimanche and Samdahl (1994) express leisure shopping in the presentation of the person's identity. Shoppers doing recreational shopping like bargain hunting and get good deals, which provide them a feeling of entertainment, acknowledging and opportunity to express one's self (Guiry et al., 2006). Babin et al, (1994) consider that for some shoppers shopping is a mean to attain a sense of accomplishment, they don't bargain for saving money. There are very studies on female consumers in the age group of 25-30 years in shopping mall scenario in Indian context. As this age group persons are new earners in their life cycles. Khare (2011) studied Indian consumers mall shopping behavior having age from 30-50 years, in which she described that female usually prefer to come to mall for shopping purpose only, or sometimes come for leisure activities but only with family, husband or kids, her priority is only family. Female consumers are the growing and lucrative market in coming years Sinha (2012), and the number of women in working sector is keep on growing, which increases the individual level buying capacity of women Khatri et al., (2008), and total annual income of women is growing more than Us\$ 1667 million (Kapoor et al., 2008). In this study we try to understand factors which are considerably important for young independent single female consumers while doing recreational shopping in malls, which in itself a complex phenomena to explain. In-depth interviews technique is used for capturing the meaning of recreational shopping in malls for intimate apparels and their meanings are elaborated through narratives of female consumers, no previous study happen on this lucrative age group and gender (. The objectives of this study are: (a) Recreational shopping experiences of shoppers (b) Conditions of recreational shopping experiences (c) meanings to recreational shopping. (d) Outcome of recreational shopping. To understand consumer decision making in malls qualitative approach is used to understand consumer behavior in malls. As it is not a new approach, Underhill (1999) used that approach to investigate consumer shopping behavior in retail settings.

\section{Literature Review Leisure shopping}

Leisure involves quantifiable and observable behavior, which may involve expenditure of money and/or time (Unger and Kernan, 1983). Leisure is associated with quantity, and considers it as existential elements extend beyond time constraints (Unger and Kerma, 1983). Leisure experiences have a pleasant effect on satisfaction, health and psychological well-being (Melamed, Meir and Samson, 1995). Leisure experiences impart meanings to recreational shopping. Leisure experiences provide psychological hedonism. The symbolic meanings related to an activity influence leisure experiences. Leisure experiences integrate with recreational shopping, help consumers to depict their self, and find out the opportunity to identify fun and fantasy (Bellenger and Korgaonkar, 1980). Leisure activities help the person to express, present and explore its self and personal identity (Dimanche and Samdahl, 1994).

\section{Recreational Shopping}

Recreational shopping provides consumer an opportunity to enjoy leisure time. It focuses on the experimental value of shopping and satisfaction feels from it, without caring much about the purchase of goods and services (Bäckstrom, 2006). It is also described as hedonic values, which are subjective and personal, and focused more fun and playfulness. It provides an entertainment and emotional worth to an individual and it purchases goods and services related to the experience of shopping (Babin, Darden, \& Griffin, 1994). Recreational shopping give chance to consumers for communicating with friends (Guiry, 1999), browse the stores, and sharing and receiving information with friends about new stores and products (Bloch et al., 1994) or they involved in more task oriented shopping (Babin et al., 1994). Consumers do shopping for both hedonic enjoyments and utilitarian benefits (Jones et al., 2006), and both the elements of shopping are present in a single shopping trip (Lehoten et al.,, 1997). The recreational shoppers might be 
anyone, a high social class woman (Gillett, 1970) who gives more importance to nature of store than anything else, or might be a middle class women who has high level of involvement in shopping and has plenty of time to roam in malls, collect and share information about product prices (Ohanian and Tashchian,1992), merchandise available or might be an information seeker or fashion seeker ((Bellenger and Korgaonkar, 1980). Sinha (2003) described that fun shoppers main objective is bargain, information and enjoyment. They do unplanned shopping for entertainment. Shopping is stress relief therapy for them, they enjoy bargaining and talking to salesperson about deals.

\section{METHODS}

The theoretical paradigm that guided this study was social constructivism (Creswell, 2003). Daly (2007) suggests two important ontological aspects within this paradigm: (a) number of realities (b) people give meaning to context differently. Individuals understand their surroundings based on their knowledge of culture and history of their world and accordingly they develop understandings, give meanings and understand the realities and finally apply the experiences in their daily lives Creswell (2003). The constructive researchers raise the issue of interaction among individuals in many environments in which they live. They take the support of grounded theory to explain the experiences of the consumers (Charmaz, 2006). This study takes the help of grounded theory, build on the consumer experiences of recrational shopping, but its interpretation is through researcher mind. Creswell (2003) also predicted that constructivist researchers design their own environment for analyzing the data. Charmaz (2006) described that theorists applying grounded theory are not themselves aware of preconceived assumptions. The authors' uses qualitative methods developed by Strauss and Quinn (1997) and interpreted by Manen (1990), and in-depth interviewing by Irving (1998), were used as guides for data collection and analysis.

\section{Data Gathering}

The study takes up Irving (1998) three-interview series model and hermeneutic-phenomenology by (Manen, 1990) to build a sense of structured creativity. The data was collected in three interview stages; First stage focus on the contextual history of the participant's lived experiences, Second stage focus on their natural lived experiences with some specific products (Fournier and Mick, 1999), and third stage focus on the reflection about their mall shopping experiences, and is there any change in thoughts about their experiences after previous interviews. Thematic conceptualization is used to nectar the essence of real captured phenomena (Manen, 1990). The next step is data reduction through inductive means (Irving, 1998). The interview questions focused on consumer recreational experiences and meaning attached to them. Open-ended interviews were conducted with five participants ages 25-30 to explore their recreational shopping experiences. All interviews were audio-taped by taking permission of participants and later transcribed for analysis and interpretation. Then intra-text strategy used for coding participant data, then inter-text strategy

Table 1

Selected demographics information of participants

\begin{tabular}{|c|c|c|c|}
\hline No. & $\begin{array}{l}\text { Participant } \\
\text { identification }\end{array}$ & Gender Age & Occupation \\
\hline & 1 Sakshi & $\mathrm{F}$ & 26 unemployed \\
\hline & 2 Uzma & $\mathrm{F}$ & 25 Accountant \\
\hline & 3 Seema & $\mathrm{F}$ & 28 Administrator \\
\hline & 4 Ragni & $\mathrm{F}$ & 30 Statistical officer \\
\hline & 5 Preeti & $\mathrm{F}$ & 26 Revenue assitant \\
\hline
\end{tabular}


used to check similarities and differences, and lastly previously interpreted texts and newly developed understandings were evaluated by comparing contexts between intra-text and intertext interpretive cycles (Thompson, 1997).

\section{Findings}

\section{Seeking Experiences}

Consumers browse and wandering in the mall without any goal, and imagining the acquisition of items and enjoy the fantasies of using the items without purchasing even a single items.

\section{Searching for Treasure}

The participants show how recreational shopping turns into treasure seeking experience for them. They stated that such opportunities on shopping give a feeling of satisfaction and accomplishment to them. The participants fell excited when they find something unexpected and searching and gathering information about it is a wonderful experience for them. The hedonic values of consumers cannot be satisfied with utilitarian aspects of shopping, these consumers want pleasure in shopping (Wang et al., 2000).

Seema: one day I was walking from nearby retail store in a mall, and I was fascinated by the looks of the mannequin girl wearing a beautiful article. I like the kurti (Indian customized shirt) on the mannequin and it was so pretty (Laughs). I called my sister to come to mall immediately with some cash and meanwhile I hold kurti tight in my hands like it is a worldly possession for me. Doesn't it excited? (Laughs)

Ragni: I usually don't like things very easily. I am very choosy in buying things and I browse a lot and compare prices. I herself don't know what I want. Sometimes I like dresses very much but because of their high price I leave them and remember the designs and wait for the sale to purchase them

Uzma: I find Titan watch on $25 \%$ discount I was very excited and the shop owner is by chance someone known to my father and offered me EMIs scheme on that watch and then I can't control myself from purchasing it. I feel like when you want something and desire it deep down in your heart you will get it and luckily the next day is my birthday (haha).

Sakshi: Shopping for me is fun. I like to check all the variety available in the stores. I feel satisfied when I check the new arrivals and the ones on sales. I check everyone item and give a look of myself in the mirror. If it is unique and suits on me, then I buy it otherwise I don't. But still I am happy that I have not skipped any new collection in the reputed stores which are famous for new collection in the whole market. I like pink dress with black strips, but it is very expensive... I like to try it in trial room but I don't because I know it suits me, and I don't need it now. I will check it on during sale.

Preeti: I like the red sari at a famous saris retail store in the mall... it was a black plain sari with red border and having red stone embroidery. My heart and eyes stick to it, it doesn't come with blouse, but doesn't matter I will stitch it by buying extra matching cloth. Its Price is INR. 15000 and the shopkeeper ready to give me at IRN. $11000 . . . m y$ friends purchase saris for marriage worth of INR. 30000 from him. It is super deal for me I don't want to lose that sari. So, I ask for some loan from my friend and I buy it.

Female consumers always in search for opportunities and when they see it, they are eager to grab that opportunity to satisfy their desire for shopping and free their mind from guilty of not buying that particular product which they like most and those guilty remains with them if they are not capable of buying their desired product. Female consumers are not in hurry on shopping they check, roam, wander in shops and select what is best for them. They always look for deals and want to enjoy the product acquisition experiences with an element of surprise. 


\section{Searching for Positive Social Exchange}

The shoppers in this study prefer to shop with those companions who have similar interest as there. If the shoppers shop with companion of dissimilar interest then they don't want any interference from companion unless asked or required. Shopping malls is a hub for social meeting for people (Roberston, 1995), and act as a pleasant place for chit chat with friends and family members (Firat and Venkatesh, 1993). Tauber (1972) people go for shopping to interact with peer groups and with person have similar interests. Shopping malls evoke and satisfy the social motives of consumers (Rintamäki et al, 2006).

Sakshi: I always like to shop with sister or with my friend Neha. It is very helpful to take someone on shopping. I don't like to shop alone it is quite boring. Shopping is platform for us to hangout, do gossips, and refresh old memories and most important shopping! (Laughs)

Ragni: I don't like shopping with someone. It feels like I have a responsibility to carry. If I am on shopping with someone I mostly do shopping for that person only. When I am alone on shopping I feel free, I can freely move in the mall enter whatever store I like. But I call my friends or parents if I find something good for them.

Seema: I usually shop with my sister Anjali, we both have same shopping preferences we both like sober colors, we are like minded kind of persons and have same approach for shopping, like I am looking for jeans and I visit 10 stores, she never give me sign of tiredness, sometimes she is more eager than me to look at the different type of variety available in the market, no matter if she doesn't have to purchase anything, if we have to do shopping for all day without having money in our pocket we are happy to do that. But when I am with my boyfriend, it is like "pick and purchase" kind of situation, when I ask him for opinions he just give smile and say yes!, if I don't like something he still give me a smile, you know I am burn out inside, but I don't say anything at that moment and make my decisions on my own, but he always support me to wear modern dresses, that is the sweetest part of him.

Uzma: I prefer to go for shopping with my friends and do fun for some moments. So, we go for everything like eating, games and shopping in the malls. We like very much to shop and hang around and watch other people activities in the malls at the same time. I like escalator ride. It is a very exciting experience while holding hand of our frighten friends while standing on the escalator especially ones having first time experience. We like to talk in English when salesperson asks in that language. I always take opinion on western dress from my friends whether my parents allow me to wear that dresses or not.

Preeti: shopping is fun and excitement for me. On shopping I have the liberty to do social outing with friends whether they are girls or boys. We go to movies, ice cream parlour, restaurants, snooker clubs, Barista or other modern coffee chains. Most of the stores where we shop remember us, know our names and we have good relations with the salespersons and store owners. They give us discounts from their own quotas, and sometimes they give us 'branded clothes!' on credit. When we leave any store it looks like a mess. But no one say anything to us I happy that I don't have boring friends.

Female consumer taking shopping in malls with excitement, they come to malls with not only expectation of shopping, but they come for other recreational features available in the mall, which gives happy moments to them which is not available in open markets. Shopping is an opportunity for girls to roam outside home with their friends, share their feelings with their companion and small town girls don't have much liberty to hangout all day as boys have with friends 


\section{Searching for self}

The participants consider shopping as an opportunity which provides them a platform to express themselves and their lifestyles. It helps them to show the society what personality they are. Consumers want recognition and distinction within the group (Scitovsky, 1992), which builds status of consumers and help to achieve prestige and honor among group members (Burn, 2004). Status conscious consumers buy only those products and brands which convey status (O,Cass and Frost, 2002). Consumers also want to build their uniqueness through brands and products (Simonson and Nowlis, 2000) to achieve distinctive self and social image. The three main categories for need for uniqueness among consumers are: (1) unique choice (2) uncommon choice, and (3) dodging resemblance of product (Tian et al., 2001).

Uzma: The product I buy for myself would represent my status and lifestyle, and I analyze lot of thinking when I give gifts to someone, because it represents me to other person. For personal clothing, I take care that dress is comfortable to me, and look nice on me, in terms of my traditions and office culture. I don't like "yank funky" dress which are uncomfortable in wearing.

Preeti: For me shopping is part of your life. I get ill without shopping. I love to shop, because shopping is a means which help me to represent my identity to others. The type of dresses I wear shows the kind of identity I am. I like to be creative and experimental in shopping styles.

Sakshi: I like to represent myself as different from others. It helps me to present myself in front of other mannerly and attractively people. I believe that what I purchase and wear represent me as what psychological type of person I am. I don't like to show how wealthy I am by wearing expensive clothing. I wear the dress which gives me attractive and elegant looks. (Laughs)!
Seema: I prefer to shop in bulks because I think I am shopaholic. I care about fashionable clothes, but I also prefer clothes which I wear in all fashions. I prefer Suits for office because there I have to present my-self differently with elegance (Laughs)!. In marriages I wear traditional saris, because it gives us a lady like look which we can't wear in offices.

Ragni: I feel more confident when I wear branded clothes than in tradiational ones. Branded clothes give me feeling of comfort and boldness to talk to others by looking directly in to their eye. In traditional dress I feel inferiority complex, especially when I give opinion to others and build trust in them. When I wear branded clothes people listen to me carefully. I think when one work hard and earn money, one should wear good dress.

In a competitive environment where there is pressure to represent in a beautiful and elegant manner. Female consumers redefine themselves in a way which might be same or different from others, but it should suits well on them. They consider dress style is the major way to represent the class from where they come and what qualities they have are easily shown through their dress style without using words.

\section{Experimental Shopping}

It talks about the obstruction that shoppers feeling when they are on shopping. It comprises of two sub-themes Task oriented shopping, and pleasant trap shopping. Recreational shoppers like to spend time in malls and involve in experimental consumption and purchase activities, and also do more impulsive buying then other consumers (Nicholls et al., 2002). In addition, these consumers are more emotional to shopping influences (Babin and Darden, 1995).

\section{Task Oriented Shopping}

Task shopping is a kind of utilitarian shopping which has facets like need and it turn shopping into less recreational. The utilitarian activity is 
also behaves as hedonic one, when the shopping process recreational in nature (Bäckström, 2006).

Preeti: Most of the time it happens, the product I am looking for is not available in the stores. I feel very bad when I don't get the dress of my imagination. So it is frustrating to change your preference and shift to the available variety in the store.

Ragni: I never preplanned the design and cut of the dress. Because I know I never find it on the shop. I only preplanned for the type of item I want and then I select the one which looks good among others inside the store

Uzma: I select shops according to the purpose of the required item. I prefer to wear normal brands for regular wear and branded items for functions and office wear. Quality is important criteria for outside wearing items and price in normal wearing items. For low price involvement products I go for experimentation shopping but for occasional shopping I have fixed shops and high budgets.

Sakshi: I make a list of items when I feel it is very urgent to shop, and then I directly go to the mall where I find everything under one roof. I shop there for almost everything on the list without searching for other brands in the same category, placed beside the required one on the aisle, and I try to get free in less time and reach back home early.

Seema: I am eagerly waiting for sales. Every day when I look at local newspaper my first concern is to look at the advertisement page to get the information of best available deals on new branded products. When I know about sale I reach to that shop and may do shopping for next same season.

Female consumers like to mix recreational shopping moods with utilitarian shopping habits. They do shopping with excitement to enjoy shopping, but when they are making their mind for real purchase in a short duration they shift their mind to utilitarian aspect of shopping to get best available offered product to get feeling of satisfaction of doing proud shopping. For need based shopping females don't like comparison and visiting different stores for the same thing. But if the females don't get the desired product they want they may shift to other type of products to fulfill the requirement.

\section{Pleasant Trap Shopping}

Sometimes consumers have bad memories of product acquisition. It is revealed by participants feeling of embarrassment when they take wrong decisions on shopping, because it's wastage of money for no reason for them.

Preeti: I think I am shopaholic. I can't control myself from shopping. When I have money I am ready for shopping, I have many desires and I get nervous when I see variety of products in the stores because my budget restrict my desires.

Sakshi: In mall I am going to purchase a shirt but I don't like it much, so I purchase trouser for me. When I come home I realized that I already have lots of pants and I don't need any more. I feel embarrassed when this happens to me, but that red trouser touches to my heart and I purchase it. It is dam crazy!

Ragni: On sale I do bulk purchasing and I feel bad afterwards. On sales the companies give lucrative offer on bulk purchasing, and I feel why I be so greed and get trap into these offers, what I will do with these similar cuts of dresses when fashion changes?, and most embarrassing moment is when I am out of money, and I have to ask from loans from friends for my small daily personal expenses.

Uzma: I feel bad when I buy something and my mother don't like it and don't allow me to wear the dress even if I get at cheaper rate or when I pay for a dress more than it's worth. My mother told me I don't have sense of shopping and I should take 
her advice for shopping, but I like the dresses very much. At home, when I am free and alone I like to test modern dresses by wearing them and looking myself in mirror for hours.

Seema: I feel bad when I purchase an item from sale and when its colour gets faded in few washes and its stitching alignment get in bad shapes after wearing it for few times. Because I known that items on sale doesn't have warrant, exchange or refundable options. But I purchase items, for freeing myself from losing something of worth in looks, which makes harder for me to take wise decisions.

The theme is about the promotional offer provided by companies to attract consumers. Female consumer feel guilty when they fall in traps design for them by companies by hiding them in lucrative offers, which prove fatal, and dampen the feeling of enjoyment and satisfaction which they expect from that product. Consumers are emotional attached with the product by looking at their features or reputation and status enjoy by these products in the market. Female consumers cannot control her mind, if they get an item of their desire, instead of feeling bad that their wardrobe having no more capacity of fitting any item in it. They like to do little transformation in their styles.

It is happened because of unplanned purchases. The time period between actual purchase and desire to purchase is so small, due to which hedonic temptation over power the individual mind and consumer don't care about consequences and go for immediate purchase (Punj, 2011; Taute and McQuitty, 2004). The temptation of the product is so high that consumer can't resist itself from buying product (Roberts and Manolis, 2012). The impulsive buying consists of three criteria's. First one is immediate action by consumer while coming under the influence of emotions, second one is consumer don't take care much about the price of the product. In third one consumer do immediate consumption because of hedonic temptations (Verhagen and Van Dolen, 2011). Consumers with hedonic values are tempted more toward promotional tactics in their product choice and brand choice (Wang et al., 2000).

\section{MANAGERIAL IMPLICATIONS}

The present study revealed consumer shopping experiences by using inductive grounded theory. Consumer recreational shopping experiences come out with two main themes (a) seeking experience and (b) experimental shopping. The first main theme describes that shoppers enjoy the shopping experience when indulge in shopping by themselves. The first main theme is further divided into three sub parts. First is searching for treasure which described that consumers are in search of best deal and when they achieve them their shopping desire gets satisfied and they have a feeling of confidence in their shopping skills. The second subtheme is searching for positive social exchange which describes the social interaction between shopper and its family members, retail salespersons and friends. The third is searching for self which emphasized the importance of shopping in representing the self of an individual. The second main theme is experimental shopping which talks about the little frustration which shoppers experience while shopping. The theme is further described by two subthemes. The first is task oriented shopping which revealed when shoppers predetermined specification for something is not fulfill it converts their desires and expectations into frustrations and reduces their excitement level. The second one is pleasant trap shopping which suggested that when consumers feeling are belittled by swindler schemes or which hurt their feeling of excitement and reduces satisfaction.

From the interviews it was analyzed that shopping give satisfaction, sense of confidence, achievement, and time constraint in defining characteristics of recreational shopping. The leisure activities create intrinsic rewards help consumers to develop motivational forces of 
'seeking and escaping' in them which lead to their satisfaction (Iso-Ahola, 1982). These intrinsic rewards create a sense of pride and achievement when consumers get something at lower a price, which was also predicted by Sternquist et al., (2004). Recreational shopping give shoppers opportunity of social interaction where they meet with their friends and boyfriends, hang out with them for some time especially in a time constraint manner. Social interactions during leisure shopping affect on seeking criteria of shopping (Mannell and Klebier, 1997), and also create an environment of interaction of shopper with friends and salespersons (Auld and case, 1997). When information exchange happens during social interaction between shopper and companion shopping becomes social activity (Younnis, 1994). All the participants also believe that their personal self style make a special place for them in the society and these activities help to build a confident image of their self in themselves and in the society. The mall environment provides them an opportunity to get social with their companions and more familiar with their family members also. The artificial decorated environment gives an opportunity to consumers to enjoy their desires and fantasies in a small environment with their companion or by looking at others. Besides these artificial fantasies consumers are excited to see ourselves with a different image and lifestyle. The same experiences were also predicted by Lehoten \& Mäenpää (1997). Dimanche and Samdahl (1994) also predicted that experimental shopping experiences help to build their self image and self concept. Along with that shopper also reveal that shopping provides them self-reward and fulfill their psychological needs. The lucrative traps garnish by stores feel guilty by consumers when they get into it with hedonic mind set and purchasing something which don't provide them good post usage affects. These traps hurt shoppers more when they lose conscious judgment because of over powering emotions, which are related to product and psychologically force the shopper to fill the emotions without analyzing the consequences. Pleasant trap feelings come after acquisition of items and embarrassments build a image of fatal love in shoppers mind set and feeling happen when consumer does compulsive shopping (O' Guinn \& Faber, 2006). The retailers have to understand the feeling and criteria of leisure shopping by the consumers to build trust worth and friendly atmosphere in the store. The retailers also have to learn how a promotion criterion which they fulfill by lucrative sales changes the shopping pattern of the consumers and their preference toward the brand or product. The same study can be further happen at discount store, mass merchandise store and online stores.

\section{CONCLUSION}

The results of the study predicted that shopping mall shopping create leisure and recreational shopping activities in the shoppers and also help them to be social with their companions and family members. The shopping satisfaction leads to shopper motivations which help shoppers to fulfill their expectations, desires and eagerness. This study focused on the five recreational shoppers who express their leisure characteristics, hedonic and utilitarian shopping values, intrinsic rewards, and meanings related to process and outcomes of recreational shopping. The shopping malls prove as a platform for leisure and enjoyable activities. But, sometimes such recreational activities create guilt for shoppers and build bad memories after sopping experiences and sometimes lower their self-confidence. 


\section{REFEREN CES}

Auld, C. J. \& Case, A. J. (1997). Social exchange processes in leisure and non-leisure settings: A review and exploratory investigation. Journal of Leisure Research, 29(2), pp. 31-43.

Bäckstrom, K. (2006). Understanding recreational shopping: A new approach. The International Review of Retail, Distribution and Consumer Research, 16(2), pp. 148-158.

Bäckström, K. \& Johansson, U. (2006). Creating and Consuming Experiences in Retail Store Environments: Comparing Retailer and Consumer Perspectives. Journal of Retailing and Consumer Services, 13, pp. 417-430. Burn, S.M. (2004). Groups: Theory and Practice. Thomson Wadsworth, Belmont, CA.

Babin, B. J. \& Darden, W. R. (1995). Consumer self-regulation in a retail environment. Journal of Retailing, 71, pp.7-70.

Babin, B., Darden, W., \& Griffin, M. (1994). Work and/or fun: measuring hedonic and utilitarian shopping value. Journal of Consumer Research, 20(4), pp. 644-656.

Bloch, P.H., Ridgway, N.M., \& Dawson, S. A. (1994). The shopping mall as consumer habitat. Journal of Retailing, 70(1), pp. $23-42$.

Belk, R. W. (1988). Possessions and the Extended Self. Journal of Consumer Research, 15, pp. 139-168.

Bellenger, D. N. \& Korgaonkar, P. K. (1980). Profiling the recreational shopper. Journal of Retailing, 56, pp. 77-91.

Charmaz, K. (2006). Constructing grounded theory: A practical guide through qualitative analysis. Thousand Oaks, CA: Sage Publications.

Creswell, J.W. (2003). Research design: Qualitative, quantitative and mixed methods approaches. Thousand Oaks, CA: Sage Publications.

Daly, K. J. (2007). Qualitative methods for family studies and human development. Los Angeles, CA: Sage Publications

DeWalt, K.M. \& DeWalt, B. R. (2002). Participant observation: A guide for fieldworkers. Walnut Creek: Altamira Press.

Dimanche, F., \& Samdahl, D. (1994). Leisure as symbolic consumption: A conceptualization and prospectus for future research. Leisure Sciences, 16(2), pp. 119-129.

Founier, S. and Mick, D. G. (1999). Rediscovering satisfaction. Journal of Marketing, 62, pp. 5-23.

Firat, A. F. \&Venkatesh, A. (1993). Post modernity: The age of marketing. International Journal of Research in Marketing, 10 (3), pp. $227-249$.

Guiry, M., Magi, A. W. \& Lutz, R. J. (2006). Defining and Measuring Recreational Shopper Identity. Journal of the Academy of Marketing Science, 34 (1), pp. 74-83.

Guiry, M. \& Lutz, R. J. (2000). Recreational shopper identity: Implications of recreational shopping for self definition. Journal of Retailing and consumer services, 21, pp. 2-15.

Guiry, M. (1999). The meaning and self-significance of recreational shopping. Doctoral dissertation presented to the Graduate School of the University of Florida.

Gillett, P. L. (1970). A profile of urban in-home shoppers. Journal of Marketing, 34, pp. 40-45.

Irving, S. (1998). Interviewing as Qualitative research: a guide for researchers in education and the social sciences. $3^{\text {rd }}$ Edition. TCP

Iso-Ahola, S. E. (1982). Toward a Social Psychological Theory of Tourism Motivation: A Rejoinder. Annals of Tourism Research, $9(2)$, pp. 256-62

Jones, M.A., Reynolds, K., \& Arnold, M. J. (2006). Hedonic and utilitarian shopping value: investigating differential effects on retail outcomes. Journal of Business Research, 59, pp. 974-981.

Jin, B. \& Sternquist, B. (2004). Shopping is truly a joy. The Service Industries Journal, 24(6), pp. 1- 18.

Khare, A. (2011). Mall shopping behavior of Indian small town consumers. Journal of retailing and consumer services, 18, pp. $110-118$.

Khatri, D. \& Pai, A. (2008). She buys to conquer. India Today. p. 27.

Kapoor, A. \& Kulshrestha, C. (2008). The effect of perception on Indian urban female consumer buying behavior. Monash Business Review, 4 (1), pp. 1-12.

Lehoten, T. \& Mäenpää, P. (1997). Shopping in the east centre mall. In Falk, P. \& Campbell, C. (Eds.), The shopping experience, London: Sage Publications. 
Martin, C.A., \& Turley, L. W. (2004). Malls and consumption motivation: An exploratory examination of older Generation Y consumers. International Journal of Retail and Distribution Management, 32(10), pp. 464-475.

Mannell, R.C. \& Kleiber, D. A. (1997). A social psychology of leisure', State College, PA: Venture Publishing.

Melamed, S., Meir, E. I., \& Samson, A. (1995). The benefits of personality-leisure congruence: Evidence and implications. Journal of Leisure Research, 27(1), 25-40.

Manen, V. (1990). Researching lived experiences, human science for an action sensitive pedagogy. Canada: State University of New York Press.

Nicholls, J. A. F., Li, F., Kranendonk, C. J. \& Roslow, S. (2002). The seven year itch? Mall shoppers across time. Journal of Consumer Marketing, 19(2), pp. 149-165.

O’Guinn, T.C. \& Faber, R. J. (2006). Compulsive buying: Review and reflection. In Haugtvedt, C.P., Herr, P., \& Kardes, F. (Eds.), Handbook of Consumer Psychology, 1-22. Mahwah, NJ: Lawrence Erlbaum Associates.

Ohanian, R. \& Tashchian, A. (1992). Consumers shopping effort and evaluation of store image attributes: the roles of purchasing involvement and recreational shopping interest. Journal of Applied Business Research, 8, p. 40.

Punj, G. (2011). Impulse buying and variety seeking: similarities and differences. Journal of Business Research, 64 (7), pp. $745-748$.

Rintamäki, T., Kanto, A., Kuusela, H. \& Spence, M. T. (2006). Decomposing the value of department store shopping into utilitarian, hedonic and social dimensions-Evidence from Finland. International Journal of Retail \& Distribution Management, 34 (1), pp. 6 - 24 .

Roberts, J. A., \& Manolis, C. (2012). Cooking up a recipe for self-control: the three ingredients of self-control and its impact on impulse buying. Journal of Marketing Theory Practices, 20 (2), pp. 173-188.

Robertson, K. A. (1995). Downtown redevelopment strategies in the United States. Journal of the American Planning Association, 61 (4), pp. 428

Taute, H., \& McQuitty, S. (2004). Feeling good! going good! An exploratory look at the impulsive purchase of the social good. Journal of Marketing Theory Practices, 12 (2), pp. 16-27.

Sinha, S. (2012). The young spenders! Parenting. THE TIMES OF INDIA. p. 15.

Sinha, P. K. (2003). Shopping Orientation in the Evolving Indian Market. VIKALPA, Vol. 28 (2), pp. 13-22.

Simonson, I., \& Nowlis, S. M. (2000). The role of explanations and need for uniqueness in consumer decision-making: unconventional choices cased on reasons. Journal of Abnormal Psychology, 86 (5), pp. 518-527.

Strauss, C., \& Quinn, N. (1997). A cognitive theory of cultural meaning. Cambridge: Cambridge University Press.

Scitovsky, T. (1992). The Joyless Economy. revised ed. Oxford University Press, New York.

Tian, K.T., Bearden, W.O., \& Hunter, G. L. (2001). Consumers' need for uniqueness: scale development and validation. Journal of Consumer Research, 28, pp. 50-66.

Thompson, C. J. (1997). Interpreting consumers: a hermeneutical framework for deriving marketing insights from the texts of consumers' consumption stories. Journal of Marketing Research, 34 (4), pp. 438-455.

Tauber, E. M. (1972). Why do people shop?. Journal of Marketing, 36, pp. 46- 49.

Underhill, P. (1999). Why we buy: the science of shopping. New York, NY: Simon and Schuster.

Unger, L.S. \& Kernan, J. B. (1983). On the Meaning of Leisure: An Investigation of Some Determinants of the Subjective Experience. Journal of Consumer Research, 9 (4), pp. 381-392.

Verhagen, T., \& van Dolen, W. (2011). The influence of online store beliefs on consumer online impulse buying: a model and empirical application', Information Management, 48 (8), pp. 320-327.

Wang, C.L., Chen, Z.X., Chan, A.K.K. \& Zheng, Z. C. (2000). The influence of hedonic value on consumer behaviours: an empirical investigation in China. Journal of Global Marketing, 14 (1/2), pp. 169-86.

Williams, T., Slama, M., \& Rogers, J. (1985). Behavioral characteristics of the recreational shopper and implications for retail management. Journal of the Academy of Marketing Science, 13(3), pp. 307-316.

Younnis, J. (1994). Children's friendship and peer culture: Implications for theories of networks and support. In F. Nestmann and K. Hurrelmann (Eds.), Social networks and social support in childhood and adolescence (pp. 75-88). Berlin: Walter de Gruyter. 